受傷アスリートとそのチームメイトが持つ認識の明確化 ${ }^{\dagger}$

鈴 木 郁 弥* 荒井弘 和 ${ }^{* *}$

\title{
Clarification of Recognition among Injured Athletes and Their Teammates $^{\dagger}$
}

\author{
Fumiya SUZUKI* and Hirokazu ARAI**
}

\begin{abstract}
It has been reported that injuries lead to psychological issues regarding human relationships while participating in sports. In particular, studies on the relationship between injured athletes and their teammates have reported that injured athletes perceive pressure from their teammates. In this study, we aimed to clarify the interpersonal recognition of injured athletes and their teammates. We conducted an investigation using a qualitative approach. Ninety-eight college student-athletes participated in this study, wherein an open-ended questionnaire was used. Written data were collected regarding the interpersonal cognition at the time of injury. The obtained data were categorized using the KJ method. According to the results, the cognition of a teammate regarding an injured athlete was categorized into 14 categories, such as "sympathy for the injured athlete", "expected to return for the injured athlete", "worry for the injured athlete", "situational awareness of the injury", and "opportunity to take the position of the injured athlete". Additionally, the injured athlete's prediction of cognition of a teammate was categorized into 12 categories, such as "expected to return for the injured athlete", "forced to return for the injured athlete", "worry for the injured athlete", "suspicion of injured athlete's sabotage", and "disinterest toward the injured athlete". From these results, it was suggested that teammates have cognition of worry and sympathy toward injured athletes, and they hope that injured athletes are cured and return to competition. In addition, it was observed that the injured athletes felt the cognition of peer-pressure in addition to the expectation of return from teammates. In the future, after collecting quantitative data, we need to examine it further by focusing on the difference between the cognition of injured athletes and their teammates.
\end{abstract}

Key words : Sports Injury, Peer Pressure, Prediction of Cognition, KJ Method, College Athlete

\section{1. 緒言}

「スポーツには怪我がつきもの」という言葉 がしばしば用いられるほど，アスリートにとっ て怪我は身近なものである。スポーツ場面にお
いて生じる怪我，すなわちスポーツ傷害は，パ フォーマンスや競技成績のみならず，スポーツ 活動への恐怖や嫌悪, 発達・発育障害, 後遺症 による機能障害など, アスリートの競技人生や 引退後の人生にまで大きな影響を及ぼす要因と

\footnotetext{
${ }^{\dagger}$ 原稿受付 2016年 8 月 22 日 原稿受諾 2016年11月22日

*法政大学研究開発センター $\quad$ T102-8160 東京都千代田区富士見 2-17-1

**法政大学文学部 †102-8160 東京都千代田区富士見 2-17-1

${ }^{*}$ Hosei University Research and Development Center, 2-17-1, Fujimi, Chiyoda-ku, Tokyo, Japan (102-8160)

* * Faculty of Letters, Hosei University, 2-17-1, Fujimi, Chiyoda-ku, Tokyo, Japan (102-8160)
} 
なりうる ${ }^{1)}$.アスリートや指導者もスポーツ傷 害の脅威を感じていることが示されており，パ フォーマンスにネガティブな影響を及ぼす要因 として, アスリート, 指導者ともにスポーツ傷 害が最も重要であると捉えている ${ }^{2)}$.

しかしスポーツ傷害は, アスリートが最大限 注意を払っていたとしても発生を完全に防ぐこ とは困難である。実際に，わが国では年間で 40.5\%もの大学生アスリートがスポーツ傷害を 負っていることが報告されており ${ }^{3)}$, スポーツ 傷害の発生を根絶することの困難さがうかがえ る。さらに, スポーツ傷害の発生に関しては, その原因のうち $18 \%$ が, 心理的な要因によるも のであることが示されており ${ }^{4)}$, スポーツ傷害 は，アクシデントや不注意といった身体的・環 境的要因だけでなく, 日常的に感じているスト レスや不安といった心理的要因とも関連してい ることが指摘されている.

スポーツ傷害に関しては, これまでは治療や リハビリテーションを前提とした知見が数多く 集積されてきた ${ }^{5)}$. しかし実際の現場では, 受 傷アスリートが必ずしも傷害に対して適切な治 療を行っていない場合もある。飯出他 ${ }^{3)}$ では, 一年間に受傷経験があった $40 \%$ のアスリートの うち 4 人に 1 人が,「受傷後, 医療機関に受診 していない」と回答したという結果が報告され ている. また，その後の傷害の状況について, 受診しなかった受傷アスリートのうちの $37 \%$ 「痛いがプレーできる」と回答したという結果 も示されている.すなわち, 傷害が完治してい ない状況にもかかわらず, 何らかの理由によっ て受傷アスリートは適切な治療よりも練習や試 合といった競技活動を優先してしまうという現 状があると報告されており, 傷害に対して適切 な治療を行わず，受傷したまま競技に復帰して しまう選手が存在していることが, この結果に よって示されている.

アスリートは傷害を負った際, 様々な問題や 困難に直面することになるが，その一つに心理 的な問題がある。受傷したアスリートが抱える 心理的な問題を扱った先行研究では, アスリー
トが受傷中に自分のポジションをチームメイト に奪われてしまう危険性を感じ, 否定的な感情

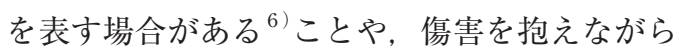
試合や練習に参加することに対してストレスを

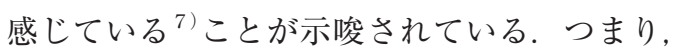
受傷アスリートは傷害そのものだけでなく, 周 囲の対人的な要因によっても，ネガティブな心 理的反応が引き起こされることが指摘されてい る.このような対人関係によって引き起こされ る心理的な問題を解消することは, 受傷アス リートの心理的健康に有益であると考えられる が，具体的な検討はほとんど行われていないの が現状である.

こうした問題を取り上げている研究は非常 に数が少ないものの, Nixon ${ }^{8)}$ およびKroshus et al. ${ }^{9)}$ において, 受傷アスリートの対人関係 によって引き起こされる心理的な問題に関する 検討が行われている. Nixon ${ }^{8)}$ では大学生アス リートを対象として, 指導者, チームメイト, アスレチックトレーナーという三者からそれぞ れ与えられる言葉がけに対して, 受傷アスリー トはプレッシャー, 落胆, 共感という感覚をど の程度持っており，それぞれに対してどのよう に対処するのかについて検討されている．結果 として, 受傷アスリートの $40 \%$ が, チームメ イトからのプレッシャーを感じていることや, チームメイトからのプレッシャーがアスレチッ クトレーナーに対する回避欲求に影響を及ぼす ことが示された.このことから, 受傷アスリー トの約半数はチームメイトからの言葉がけをプ レッシャーに感じていることが示されている. また，復产や練習を求められていると考えるた めに，身体的なケアや健康管理を担当している アスレチックトレーナーとの接触を回避してし まう可能性があることが示唆されている.

また, Kroshus et al. ${ }^{9)}$ は, 大学生アスリー トを対象に脳震とうを負った際の周囲への報告 意思に対して, 脳震とうの経験や知識, その後 のプレー継続経験, 周囲からのプレッシャーと いった要因がどの程度影響を及ぼすかを検討し ている。その結果として，チームメイトからプ 
レッシャーを受けるほど脳震とうを報告しなく なることが示された。また，受傷アスリートが 脳震とうに関する経験や知識を持っていても, アスリートが周囲の人間に対して報告をしよう とする意思は増加しないことも示されている. つまり，脳震とうを早期に発見・処置するため の効果的な手段である, 受傷したアスリート本 人からの自己報告を促すためには，脳震とうの 危険性に関する知識をアスリートに対して教え るよりも，チームメイトからのプレッシャーを 低減させることが重要であるということが明ら かとなった。

このように, チームメイトが持つ,「受傷ア スリートに対する認識」（以下本論では,「認識」 という語を用いる）が，先行研究において扱わ れている。そして，チームメイトという存在が 受傷アスリートに対して影響を与える要因と なっており，チームメイトが受傷アスリートに 与えるプレッシャーは, 受傷アスリートの治療 に対する意思や行動を阻害する要因であること が，2つの研究によって明らかにされている.

しかし，これらの研究 ${ }^{819)}$ こおいて扱われて いるのは, チームメイトがどのような認識を 持っていると受傷アスリート自身が感じるかと いう「チームメイトの認識に対する推測」(以 下本論では,「推測」という表現を用いる）で あり, チームメイトの認識については, 先行研 究では全く言及されていないという問題点が ある、スポーツ傷害以外に打けるアスリートの 二者間の関係性に着目した研究では, アスリー トとコーチの相互的な関係性を明らかにするた め, アスリート・コーチの両者を調查対象とし て質問紙調查を行い，比較検討が行われている 2). スポーツ傷害発生時における受傷アスリー トとチームメイトの関係性においても, 両者の 関係性に着目して検討を行うことによって，よ り包括的, 多角的な知見を収集することができ ると考えられるため, チームメイトの認識と， 受傷アスリートの推測という両者の立場から検 討を行う必要があるだろう。

また, 先行研究 ${ }^{8)}$ 9)では, 受傷アスリートの
「プレッシャー」「落胆」「共感」という 3 種類 の推測に限定されており, それ以外の種類につ いては言及されていないという問題もある. 確 かに，受傷アスリートの治療に対して影響を与 える要因を明らかにしたことには大きな意義が ある、しかしそもそも，受傷アスリートとチー ムメイトの間で生起している認識や推測の種類 について，これまでの知見では明らかにされて いない.まずは受傷アスリートやチームメイト が持つ認識の種類を網羅したうえで，それぞれ の認識の程度や受傷アスリートの治療に対する 影響を検討する必要があるだろう。

そこで本研究では, 対人関係によって生じる 受傷アスリートの心理的な問題を解消するため の足がかりとして，まずは受傷アスリートと チームメイトの関係性に着目し，受傷アスリー トとチームメイトが，それぞれ互いに考える認 識の種類を明確化することを目的とした。具体 的には，大学生アスリートを対象とした自由記 述形式の質問紙調查を実施し, 受傷アスリート の認識とチームメイトの推測について質的デー 夕を収集し, 認識や推測の種類を明確化する.

\section{2. 方法}

\section{1 調査対象者}

首都圈にある 4 年制大学の体育会部活動に所 属する大学生98名を調查対象とした，本研究に おける調查対象者をこのように選定した理由と して，大学生アスリートは他の年齢層に比べ てスポーツ経験年数が多く, 対象者自身が傷害 を負ったり，チームメイトが傷害を負うという 状況を経験したことがある可能性が高いことか ら, より具体的かつ多様性のある回答を得るこ とができると判断したためである.

\section{2 調査時期}

調查時期は2014年 7 月であった.

\section{3 調査項目}

（1）属性：性別, 年齢, 学年, 所属部活名, 現在行っているスポーツの経験年数, 部活内の 
地位 (レギュラー・準レギュラー・非レギュラー) について回答を求めた.

(2) 痛みの評価スケール：対象者が現在抱え ている傷害の程度を測定するため, 本研究では, 傷害によって引き起こされる主観的な身体の痛 みについて, 臨床場面において身体的な疼痛を 測定するための尺度として広く用いられている Numerical Rating Scaleを使用した. 具体的に は, 現在抱えている痛みについて，0（痛みな し） -10 (耐えられない痛み）をそれぞれ両端 に設定し，０－10の11段階で評価を求めた.

（3）受傷アスリートの認識：受傷アスリート の認識にどのようなものがあるのかを明確化す るため，想定法による回答を行ってもらった。 具体的には,「あなたの周りに, 怪我や身体の 痛みを抱えているために十分な練習ができない 選手がいるとき，あなたはその選手に対してど のようなことが思い浮かびますか」という教示 を行い, 自由記述形式で回答を求めた.

(4)チームメイトの推測 : チームメイトの推 測にどのようなものがあるのかを明確化するた め, 想定法による回答を行ってもらった。具体 的には,「あなたが怪我や身体の痛みを抱えて いるために十分な練習ができないとき，チーム メイトは, あなたに対してどのように思ってい ると感じますか」という教示を行い, 自由記述 形式で回答を求めた。

\section{4 手続き}

大学の講義開始前を利用して質問紙の配布・ 回収を行った。 その際, 参加同意書を事前に配 布し, 研究参加の同意を得た上で, 質問紙の配 布・回収を行った。なお, 参加同意書には, 本 研究の目的や所要時間, 回収した質問紙やデー 夕の取り扱い方法, 本研究から得られる結果の フィードバック方法, 研究者の情報と連絡先に ついて明記した，そして，対象者が回答をいつ でも中断できる権利を明記し, 倫理的な配慮を 行った.

なお本調査は, 法政大学文学部心理学科・心 理学専攻倫理委員会において審査を受け, 研究
実施の承認を得た上で実施された。

\section{5 分析方法}

自由記述によって得られた回答を整理・集約 する方法として, 本研究では $\mathrm{KJ}$ 法 $^{10)}$ を採用し た．KJ法とは，「紙切れ作り」「グループ編成」 $\lceil\mathrm{A}$ 型図解化」「B型文章化」という４つのステッ プによって，質的なデー夕を分類し新たな理論 を「発想」することを主眼とした定性的分析で あり，質的研究において広く用いられている手 法である。このうち「 $\mathrm{A}$ 型図解化」「 $\mathrm{B}$ 型文章 化」については, 編成されたグループごとの関 係性や因果性を構築するために行われるが, 本 研究では, 認識の種類を明確化するという研究 目的を考慮し，この 2 つのスップについては 省略した。 よって本研究では, KJ 法の 4 つの ステップのうち，1つ目の「紙切れ作り」およ び2つ目の「グループ編成」に基づいて分析作 業を行った．報告された回答を改変することな く1つずつ紙切れにした上で, 作業者間で議論 を行い, 研究目的に鑑みて, 同意にいたるまで 吟味・検討し，それらの紙切れをカテゴリに整 理・集約した. 議論の際に集約が困難だと判断 された回答については, 無理に他のカテゴリに 集約することはせず，独立したカテゴリに集約 した．意味が不明瞭な回答や目的にそぐわない 回答は分析の過程で除外した。なお，これらの 作業は心理学を専攻とする大学教員 1 名と心理 学専攻の大学院生 1 名, 心理学を専攻し体育会 部活動に所属する大学生 2 名の計 4 名によって 行われた。

\section{3. 結果}

\section{1 対象者の人口統計的データ}

98名を対象に質問紙を配布し, 回収率は $100 \%$ であた。分析対象となった 98 名のうち, 男性は72名, 女性は26名であり, 平均年齢は 18.72 歳 $(S D=0.78)$ であった. 対象者の所属 部活動は, アメリカンフットボール部12名, 硬 式野球部11名, フェンシング部 9 名, ボート部 8 名, レスリング部 7 名, スケート部 7 名, 卓 
球部 5 名, バドミントン部 4 名, バレーボール 部 4 名, ボクシング部 4 名, 弓道部 4 名, 剣道 部 4 名, ゴルフ部 3 名, バスケットボール部 3 名, 柔道部 3 名, 自転車競技部 2 名, 重量挙部 2 名, 水泳部 2 名, 相撲部 2 名, スキー部 1 名, 空手部 1 名であった。対象者が現在行っている スポーツの競技継続年数は平均 8.52 年 $(S D=$ 4.16）であり, 部内の地位については, レギュ ラーが24名, 準レギュラーが22名, 非レギュラー が52名であった．現在抱えている身体的な痛み の程度は平均3.99（ $S D=2.85 ）$ であった。

\section{2 チームメイトの認識の分類}

チームメイトの認識について, 110の自由記 述回答が得られた。このうち 7 の回答について は, 不明瞭な内容や目的にそぐわないと判断 されたため, これらの回答を除いた103の回答 を整理・集約した。集約された結果の一部を

Table 1に示す.

結果として,【受傷者に対する同情】【受傷者 の復帰への期待】【受傷者に対する心配】【受傷 者の怪我の状況把握】受傷者の地位を奪うチャ ンス】【受傷者に対する休息の推奨】【受傷者に 対する行動的援助】【受傷者に対する羡望】【受 傷者に対する心理的援助】【受傷者に対する復 帰の強要】【受傷者の対処方略に対する働きか け】【受傷原因の追究】【受傷に関する発想の転 換】【受傷者に対する無関心】という14のカテ ゴリが得られた。

各カテゴリに含まれた具体的な回答につい て，【受傷者に対する同情】には，「大変そうだ な」「かわいそう」など, 受傷したアスリート への思いやりを表す回答がまとめられた。【受 傷者の復帰への期待】には,「早く治してほしい」 「早くまた一緒に練習したい」など, 受傷アス リートが再度練習に復帰することを望み願う回 答が分類された.【受傷者に対する心配】には, 「大丈夫かな」「心配する」など，受傷アスリー トを案ずる回答が含まれた、【受傷者の怪我の 状況把握】には,「どこが痛いのかな」「怪我は 大きいのか, 小さいのか, すごく心配」など,
受傷アスリートの抱える傷害そのものに興味を 持っている回答が集約された.【受傷者の地位 を奪うチャンス】には,「ここで差をつけてやる」 「ケガをしてレギュラーを取るチャンス」など, 受傷アスリートが練習に参加できない中, 自分 が努力することで受傷アスリートとの実力差を つけたいという意思が表された回答が含まれ た.【受傷者に対する休息の推奨】は，「きちん と休んだ方がいいのではないか」「無理をせず しっかりと治してから練習に参加すればよいと 思う」など，受傷アスリートの傷害を完治させ るため，一時的に休息を取ることを勧める回答 が分類された、受傷者に対する行動的援助】は, 「その人の分まで仕事をしてあげる」「助けてあ げる時があれば助けよう」など，受傷中の競技 生活で何らかの障害があった場合に, 行動によ る手助けをしてあげようとする回答が類型化さ れた、【受傷者に対する羡望】には，「楽そうだ と思う」「サボりなのかな」など，傷害を抱え ているために通常通りの練習メニューをこなす ことができないアスリートに対して羡ましく感 じている回答が含まれた、【受傷者に対する心 理的援助】は，「とりあえず励ます」「怪我して る人に優しく接する」など, 受傷アスリートが 苦痛な心境であると推察し, 心理的なケアをし ようとする回答にまとめられた、【受傷者に対 する復帰の強要】は,「早く練習をしてほしい」 $\lceil 100 \%$ プレーできるなら合流して」など, 傷害 の治療よりも練習場面への復帰を強く求める回 答で構成された。【受傷者の対処方略に対する 働きかけ】には、「言ったほうがいいんじゃな いか」「医者の言うことを聞かせる」など，受 傷アスリートに対して具体的な方略を提案しよ うとする回答が含まれた、【受傷原因の追究】は, 「やりすぎではないかな」「自己管理ができてい ない」のように，アスリートが傷害を負ってし まった原因について考察をしている回答にまと められた、【受傷に関する発想の転換】は,「苦 しさをバネに頑張ってほしい」「休むことから 学べることもあると思う」のように，受傷した という事実について，ネガティブな影響ばかり 
Table 1 チームメイトの認識の分類結果

\begin{tabular}{|c|c|}
\hline カテゴリ名（回答数） & 主な回答（重複していた回答の数） \\
\hline 受傷者に対する同情（18） & $\begin{array}{l}\text { 大変そうだな }(3) \\
\text { 大変だなと思う }(2) \\
\text { かわいそう (2) }\end{array}$ \\
\hline 受傷者の復帰への期待（17） & $\begin{array}{l}\text { 早く治してほしい }(4) \\
\text { ゆっくり休んでもらいたい }(2) \\
\text { 早くまた一緒に練習したい }(2)\end{array}$ \\
\hline 受傷者に対する心配（14） & $\begin{array}{l}\text { 大丈夫かな (4) } \\
\text { 心配する (3) } \\
\text { 心配 (3) }\end{array}$ \\
\hline 受傷者の怪我の状況把握（10） & $\begin{array}{l}\text { どこが痛いのかな } \\
\text { どの程痛いのか気になる } \\
\text { 怪我は大きいのか, 小さいのか, すごく心配 }\end{array}$ \\
\hline 受傷者の地位を奪うチャンス（8） & $\begin{array}{l}\text { ここで差をつけてやる } \\
\text { ケガをしてレギュラーを取るチャンス } \\
\text { 同期の場合ここで差をつける }\end{array}$ \\
\hline 受傷者に対する休息の推奨（7） & $\begin{array}{l}\text { きちんと休んだ方がいいのではないか } \\
\text { ひどくなる前に治せ } \\
\text { 無理をせずしっかりと治してから練習に参加すればよいと思う }\end{array}$ \\
\hline 受傷者に対する行動的援助（6） & $\begin{array}{l}\text { その人の分まで仕事をしてあげる } \\
\text { 助けてあげる時があれば助けよう } \\
\text { 手伝ってあげる }\end{array}$ \\
\hline 受傷者に対する羡望（4） & $\begin{array}{l}\text { 楽そうだと思う（2） } \\
\text { つらい練習をしているならせこいと思う } \\
\text { サボりなのかな }\end{array}$ \\
\hline 受傷者に対する心理的援助（3） & $\begin{array}{l}\text { とりあえず励ます } \\
\text { 声かける } \\
\text { 怪我してる人にやさしく接する }\end{array}$ \\
\hline 受傷者に対する復帰の強要（3） & $\begin{array}{l}\text { 早く治せよ } \\
\text { 早く練習をしてほしい } \\
100 \% \text { プレーできるなら合流して }\end{array}$ \\
\hline 受傷者の対処方略に対する働きかけ（3） & $\begin{array}{l}\text { 言った方がいいんじゃないか } \\
\text { 病院に行ってしっかり見てもらう } \\
\text { 老者の言うことを聞かせる }\end{array}$ \\
\hline 受傷原因の追究（2） & $\begin{array}{l}\text { やりすぎではないかな } \\
\text { 自己管理ができていない }\end{array}$ \\
\hline 受傷に関する発想の転換（2） & $\begin{array}{l}\text { 苦しさをバネに頑張ってほしい } \\
\text { 休むことから学べることもあると思う }\end{array}$ \\
\hline 受傷者に対する無関心 (2) & $\begin{array}{l}\text { とくに思いうかばない } \\
\text { 特に興味を持たないので何も思わない }\end{array}$ \\
\hline その他 & $\begin{array}{l}\text { 十分なパフォーマンスもできなくてかわいそうだと思うけど } \\
\text { すごいと思う } \\
\text { 練習メニューは何してるのかな } \\
\text { しょうがない } \\
\text { あえて鬫しく }\end{array}$ \\
\hline
\end{tabular}


でなくポジティブな影響もあるのではないかと 考える回答が分類された。【受傷者に対する無 関心】には，「特に思いうかばない」「特に興味 を持たないので何も思わない」のように, 受傷 アスリートや傷害についての印象が特にないこ とを報告する回答が集約された。また，これら のカテゴリに当てはまらなかったものとして, 「十分なパフォーマンスもできなくてかわいそ うだと思うけどすごいと思う」「練習メニュー は何してるのかな」「しょうがない」「あえて厳 しく」という回答が挙げられていた.

\section{3 受傷アスリートの推測の分類}

受傷アスリートの推測について, 109の回答 が得られた。このうち, 不明瞭な内容や目的に そぐわない回答が 6 あったため, これらの回答 を除いた103の回答を整理・集約した。集約さ れた結果の一部をTable 2に示す.

結果として,【受傷者の復帰への期待】【受傷 者に対する復帰の強要】【受傷者に対する心配】 【受傷者に対するサボタージュの疑念】【受傷者 に対する無関心】受傷者の怪我の状況把握】受 傷者に対する否定的評価】【受傷者に対する同 情】【受傷者に対する休息の推奨】【受傷者に対 する怪我に配慮した練習の推奨】【受傷原因の 追究】【受傷者に対する最善の努力の推奨】と いう12のカテゴリが得られた。

【受傷者の復帰への期待】には,「早く治し てほしい」「早く復活してほしい」など, チー ムメイトから復帰を望まれ期待されていると推 察する回答が含まれた。【受傷者に対する復帰 の強要】は,「早く治せ」「早く治して復帰しな さい」など，いち早い完治や復帰を強く望まれ ており, 半ば強要されていると推察している回 答のまとまりとなった、【受傷者に対する心配】 は，「心配してくれていると思う」「心配してい る」など，チームメイトから身を案じられてい ると想像する回答が類型化された。【受傷者に 対するサボタージュの疑念】は，「サボってい る」「サボるなと思われる」など, 傷害を負っ ているために十分な練習ができないと, チーム
メイトは自分が練習に全力を尽くしていないと 感じているのではないかと考える回答によって 構成された、【受傷者に対する無関心】には,「何 も思っていない」「無関心」など，チームメイ トは受傷中の自分や傷害に対して具体的な印象 を持っていないのではないかと推察する回答が 要約された.【受傷者の怪我の状況把握】には, 「どこか痛いのか」「ほんとに痛いのかな」など, チームメイトは自分が負っている傷害について の興味や疑問を持っているのではないかと推察 する回答が分類された、【受傷者に対する否定 的評価】には，「少し視線が冷たく感じること がある」「ヘタレ」など，チームメイトから否 定的な印象や評価を持たれているのではないか と想像する回答が含まれた。【受傷者に対する 同情】には，「かわいそう」「かわいそうだけど しょせん他人事」など，チームメイトから心的 な距離を置かれていることを感じつつも，傷害 を負っているという境遇に対しては同情をして くれているのではないかと考える回答が含まれ た、【受傷者に対する休息の推奨】には，「休ま せたほうがいいと感じている」「全力でできな いのならしょうがないのでゆっくり休んでほし い」など, 治療のために練習への参加を中断し, 休息を取ったほうがよいと考えているのではと 推察する回答がまとめられた、【受傷者に対す る怪我に配慮した練習の推奨】は,「他のトレー ニングをするチャンスだ」「治るまでは他のメ ニューをして頑張ってほしい」など, 通常の練 習メニューはこなすことができないということ を理解してくれており, 受傷アスリートに対し て用意される専用の練習メニューを頑張ってほ しいと思われていると推察する回答によって構 成された、【受傷原因の追究】には，「うまく付 き合わなくてはならないケガだからな」「ちゃ んとストレッチをしてないからだ」など, チー ムメイトが受傷した原因や傷害の特徵などに対 して印象を持っていると想像する回答が含まれ た.【受傷者に対する最善の努力の推奨】には, 「できることはしとけ」「怪我をしていてもでき ることはしっかりやってください」など, 受傷 
Table 2 受傷アスリートの推測の分類結果

\begin{tabular}{|c|c|}
\hline カテゴリ名 (回答数) & 主な回答 (重複していた回答の数) \\
\hline 受傷者の復帰への期待 (19) & $\begin{array}{l}\text { 早く治してほしい }(5) \\
\text { 早く復活してほしい }(2) \\
\text { 早く治して早く復帰してほしい }(2)\end{array}$ \\
\hline 受傷者に対する復帰の強要 (14) & $\begin{array}{l}\text { 早く治せ }(3) \\
\text { 早く治せよ }(2) \\
\text { 早く治して復帰しなさい }\end{array}$ \\
\hline 受傷者に対する心配 (11) & $\begin{array}{l}\text { 心配してくれている }(3) \\
\text { 心配している }(2) \\
\text { 心配していると思う }\end{array}$ \\
\hline 受傷者に対するサボタージュの疑念 (10) & $\begin{array}{l}\text { サボっている }(2) \\
\text { サボるなと思われる } \\
\text { サボっていると思う }\end{array}$ \\
\hline 受傷者に対する無関心 (10) & $\begin{array}{l}\text { 何も思っていない }(2) \\
\text { 特に何も思ってないと思う }(2) \\
\text { 無関心 }(2)\end{array}$ \\
\hline 受傷者の怪我の状況把握 (7) & $\begin{array}{l}\text { どこか痛いのか }(3) \\
\text { どこか痛いのか心配している } \\
\text { ほんとに痛いのかな }\end{array}$ \\
\hline 受傷者に対する否定的評価 (6) & $\begin{array}{l}\text { 少し視線が冷たく感じることがある } \\
\text { ヘタレ } \\
\text { 自分に甘いやつだな }\end{array}$ \\
\hline 受傷者に対する同情 (6) & $\begin{array}{l}\text { かわいそう (3) } \\
\text { かわいそうだなと思っていると感じる } \\
\text { かわいそうだけどしょせん他人事 }\end{array}$ \\
\hline 受傷者に対する休息の推奨 (5) & $\begin{array}{l}\text { しっかり休んだ方がいいんじゃない?と感じる } \\
\text { 休ませた方がいいと感じている } \\
\text { 全力でできないのならしょうがないのでゆっくり休んでほしい }\end{array}$ \\
\hline $\begin{array}{l}\text { 受傷者に対する怪我に配慮した練習の } \\
\text { 推奨 (4) }\end{array}$ & $\begin{array}{l}\text { 他のトレーニングをするチャンスだ } \\
\text { 治るまでは他のメニューをして頑張ってほしい } \\
\text { 体づくりをさせる }\end{array}$ \\
\hline 受傷原因の追究 (4) & $\begin{array}{l}\text { うまく付き合わなくてはならないケガだからな } \\
\text { 肩は前から故障持ってるからな } \\
\text { ちゃんとストレッチをしてないからだ }\end{array}$ \\
\hline 受傷者に対する最善の努力の推奨 (2) & $\begin{array}{l}\text { できることはしとけ } \\
\text { 怪我をしていてもできることはしっかりやってください }\end{array}$ \\
\hline その他 & $\begin{array}{l}\text { 自分が目立つチャンス } \\
\text { こいつ練習できなくていいな } \\
\text { 仕方ない } \\
\text { 接してもらっていないのでわからない } \\
\text { わからない }\end{array}$ \\
\hline
\end{tabular}


中であっても, チームメイトのサポートなどを 行うことによってチームへの積極的な参加をす るべきだとチームメイトが考えているのではな いかと推察する回答が集約された。また，これ らのカテゴリに当てはまらなかったものとし て,「自分が目立つチャンス」「こいつ練習でき なくていいな」「仕方ない」「接してもらってい ないのでわからない」「わからない」という回 答が挙げられていた。

\section{4. 考察}

\section{1 チームメイトの認識}

$\mathrm{KJ}$ 法によって分類されたチームメイトの認 識に関して，【受傷者に対する同情】【受傷者の 復帰への期待】受傷者に対する心配】といった, 受傷アスリートを気遣う回答が特に多く見られ た.このことから, チームメイトは心配や同情 の認識を持っており，また傷害の完治や競技へ の復帰を願う気持ちも持っていることがうか がえる，そのうえで,【受傷者の怪我の状況把 握】【受傷者に対する行動的援助】【受傷者に対 する心理的援助】など, 傷害の具合を正しく理 解しょうという認識を持っており, 心理的・行 動的なサポートを積極的に行うことで, 受傷ア スリートの競技復帰を手助けしたいと考えてい ることが示唆される、また,【受傷に関する発 想の転換】のように, 受傷することでのみ得ら れる経験や，そこから学ぶことのできることが あることから，傷害はアスリートにとってネガ ティブな要因となるだけではなく, むしろポジ ティブな要因としても活用できると考えるチー ムメイトも存在することがうかがえる，ただし これは, チームメイトが他人事として回答して いる可能性もあるため, 傷害をポジティブに捉 えていたチームメイト自身が受傷した際にも同 様に考えるかどうかは, 不明であると留意する 必要があるだろう。

その一方で，【受傷者の地位を奪うチャンス】 【受傷者に対する羡望】のように, 満足に練習 をこなすことができない受傷アスリートに対し て美ましいと感じたり, 自分が努力することに
よって部内の地位を奪取しようと考えているこ とも示された，そして，【受傷者に対する復帰 の強要】のように, 通常の練習をこなすことが できない受傷アスリートに対して不満を感じた り, チームとしてのパフォーマンス低下を危惧 すると, チームメイトは復帰を強要する認識が 芽生えることが示唆される.

\section{2 受傷アスリートの推測}

次に, 受傷アスリートの推測の分類結果だが, 今回の調查では【受傷者の復帰への期待】【受 傷者に対する復帰の強要】という相反する 2 つ の推測が特に多く見られた。このことから，受 傷アスリートは，チームメイトが復帰に関して 気にかけていると推察していることが示唆され る.そして，チームメイトから【受傷者に対す る心配】や【受傷者に対する同情】を向けられ ていると感じつつも，【受傷者に対するサボター ジュの疑念】【受傷者に対する否定的評価】の ように，練習を満足にこなすことができないこ とに対して否定的に見られていると推察してい ることが示された。

また,【受傷者の怪我の状況把握】【受傷原因 の追究】のように，傷害そのものに関する推測 を持っており、【受傷者に対する休息の推奨】【受 傷者に対する怪我に配慮した練習の推奨】【受 傷者に対する最善の努力の推奨】のように，傷 害の具体的な対処方略に関する推測を持ってい ることが示唆される。

\section{3 チームメイトの認識と受傷アスリート の推測の比較}

チームメイトの認識と受傷アスリートの推測 を比較してみると,【受傷者の復帰への期待】 【受傷者に対する復帰の強要】【受傷者に対する 心配】【受傷者に対する同情】といった，受傷 アスリートの復帰や精神的な援助に関する回 答や,【受傷者の怪我の状況把握】【受傷者に 対する休息の推奨】【受傷原因の追究】といっ た，傷害そのものに関する回答が共通して見ら れた。このことから, チームメイトは受傷アス 
リートに対して, 精神的な気遣いや怪我そのも のに対して関心を持っており, 受傷アスリート は，そうしたチームメイトの認識をおおむね正 しく推察していることが示唆される.

また, チームメイトの認識においてのみ得ら れたカテゴリは【受傷者の地位を奪うチャンス】 【受傷者に対する美望】【受傷に関する発想の転 換】【受傷者に対する心理的援助】【受傷者に対 する行動的援助】であり, 受傷アスリートの推 測においてのみ得られたカテゴリは【受傷者に 対するサボタージュの疑念】【受傷者に対する 否定的評価】【受傷者に対する怪我に配慮した 練習の推奨】【受傷者に対する最善の努力の推 奨】であった。このうち【受傷者の地位を奪う チャンス】【受傷者に対する羡望】【受傷に関す る発想の転換】【受傷者に対するサボタージュ の疑念】【受傷者に対する否定的評価】といっ たカテゴリは, 練習を満足に行うことができな い状況に関する認識であり, チームメイトは受 傷アスリートが練習を行うことができないとい う状況を見て，「楽そうだと思う」という【受 傷者に対する羡望】や, 受傷アスリートを追い 抜き【受傷者の地位を奪うチャンス】を感じて いた。一方, 受傷アスリートはチームメイトか ら【受傷者に対するサボタージュの疑念】【受 傷者に対する否定的評価】といった否定的な評 価をされていると考えており，傷害の影響で自 分の評価が悪くなってしまうことを推察してい た.これらのカテゴリは, 部内での評価や地位 が変動することに関する認識という点において 共通していると考えられる。 またチームメイト は, 受傷アスリートという存在が部内の評価や 地位といった基準に影響を与える要因だと考え ており，チームメイト自身のモチベーションに も関与することが, この結果から示唆すること ができる.

そして,【受傷者に対する心理的援助】【受傷 者に対する行動的援助】【受傷者に対する怪我 に配慮した練習の推奨】【受傷者に対する最善 の努力の推奨】といったカテゴリは, 受傷アス リートや傷害の援助に関する回答である。受傷
アスリートとしては, 自分の傷害についてチー ムメイトから正しく理解されていると感じてお り,「できることはしとけ」といった【受傷者 に対する最善の努力の推奨】をすることや,「他 のトレーニングをするチャンスだ」といった【受 傷者に対する怪我に配慮した練習の推奨】など の具体的な提案をチームメイトが考えていると 推察していた。一方, チームメイトは受傷アス リートに対して「その人の分まで仕事をしてあ げる」や「とりあえず励ます」といった，行動 的・心理的な援助を通じて受傷アスリートを気 遣扮うと考えていた。これらの回答は，援助の 認識があるという点において共通しているとい えるだろう。

ただし，チームメイトが持っていた援助の認 識には，受傷アスリートや傷害に対する具体的 な援助よりも，「とりあえず励ます」「助けてあ げる時があれば助けよう」といった，抽象的な 表現が多く含まれていた。 アスリートが受傷し た際，通常とは異なるメニューで練習に参加す ることがある。また，受傷アスリートは否定的 な感情やストレスを感じてしまう場合がある ${ }^{6 / 7)}$ とも言われている。こうした状況に置かれるこ とで, 受傷アスリートとチームメイトの関わり が減少し, 受傷アスリートが求めている具体的 な対応や援助をチームメイトが正確に把握でき ない状況が生まれている可能性が考えられる. よって, 受傷アスリートに対して, より具体的 で受傷アスリートのニーズに沿った援助をチー ムメイトが行うためには, こうした状況を改善 する必要があるかもしれない.

\section{4 本研究の限界点と今後の展望}

本研究では想定法によって調查が行われてお り, 実際に受傷している状況で測定されている わけではない. よって今後は, 実際の受傷アス リートとそのチームメイトに対しても同様の調 査を行うことで，より正確な実態が反映された 知見を示す必要があるだろう。また本研究で は, 受傷アスリートやチームメイトの受傷状況 や過去の受傷経験に関する指標が測定されてい 
ない. しかし実際には, こうした経験によって 想起される認識が変わる可能性は十分に考えら れる. よって今後の調査では, 傷害に関する具 体的な項目を測定し, 受傷経験によって認識に 違いが見られるかを検討することも必要である と考えられる.

今後は, 本研究で得られた結果を元に質問項 目を作成し, チームメイトの認識と受傷アス リートの推測における定量的なデータを収集す ることで, 両者の差異を定量的に検討すること が期待される。 また, 受傷アスリートの個人特 性や所属する集団の特性, チームメイトとの関 係性といった要因との関係性について検討する ことも望まれる.

\section{5. 結}

論

本研究の目的は, 受傷アスリートとチームメ イトの両者に生じる認識について質的な手法を 用いて類型化することであった。本研究では, 自由記述形式で収集したテキストデータを $\mathrm{KJ}$ 法によって整理·集約し, 受傷アスリート・チー ムメイトがそれぞれ互いに持つ認識を分類し た. 結果として，【受傷者に対する同情】【受傷 者の復帰への期待】【受傷者に対する心配】【受 傷者に対する無関心】などの認識に分類された。 また，受傷アスリートだけでなくチームメイト に対しても同様の調查を行ったことにより, 受 傷アスリートとチームメイトがそれぞれに持つ 認識の特徵や, 双方の認識における意味づけの 違い, 一方的な推測が行われていることなども 明らかとなった。

\section{謝辞}

本研究を行うにあたり, 法政大学文学部の吉 村浩一先生および渡辺弥生先生には, 多大なる ご助力を頂きました。この場をお借りして感謝 の意を表します。

\section{参 考 文 献}

1 ）青木邦男, 松本耕二 ; スポーツ外傷・障害と 心理社会的要因, 山口県立大学看護学部紀要, Vol.3, pp.9-19, 1999.

2 ) Ruiz-Tendero G. and Martín J. J. S. ; Psycho-social factors determining success in highperformance triathlon: Compared perception in the coach-athlete pair, Perceptual and Motor Skills, Vol.115, No.3, pp.865-880, 2012.

3 ）飯出一秀, 他; 大学スポーツ選手に打けるス ポーツ外傷・障害の現状と対策 - 第 2 報 - , 環 太平洋大学研究紀要, Vol.5, pp.117-124, 2012.

4 ) Smith A. M., et al. ; Emotional responses of athletes to injury, Mayo Clinic Proceedings, Vol.56, pp.38-50, 1990.

5 ) 直井愛里 ; スポーツ傷害における心理学, 近 畿大学臨床心理センター紀要, Vol.2, pp.35-40, 2009.

6 ) Podlog L. and Eklund R. C. ; A longitudinal investigation of competitive athletes' return to sport following serious injury, Journal of Applied Sport Psychology, Vol.18, No.1, pp.4468, 2006.

7 ) Mellalieu S. D., et al. ; Competition stress in sport performers: Stressors experienced in the competition environment, Journal of Sports Sciences, Vol.27, No.7, pp.729-744, 2009.

8 ) Nixon L. H. ; Social pressure, social support, and help seeking for pain and injuries in college sports networks, Journal of Sport and Social Issues, Vol.18, No.4, pp.340-355, 1994.

9 ) Kroshus E., et al. ; Concussion under-reporting and pressure from coaches, teammates, fans, and parents, Social Science and Medicine, Vol.134, pp.66-75, 2015.

10）川喜田二郎；続・発想法 $-\mathrm{KJ}$ 法の展開と応用一, 中央公論新社, 1970. 